\title{
Chemical composition and protein digestibility of chloroplastic concentrates from lucerne juice coagulated using various methods
}

\author{
Barbara Baraniak \\ Department of Biochemistry and Food Chemistry, \\ Lublin Agricultural Academy \\ Akademicka 15, 20-934 Lublin, Poland
}

(Received 19 September 1996; accepted 6 February 1997)

\begin{abstract}
The chemical composition of protein concentrates from lucerne prepared by various methods was compared. Chloroplastic concentrates of lucerne juice (var. Kleszczewska) were precipitated by centrifugation ( $3000 \mathrm{rpm}$ ), heating ( $328 \mathrm{~K}$ ), and with flocculants (Magnafloc LT-26 and Superfloc A-115). The following were analyzed: crude and true protein, carotenoid and chlorophyll contents, fatty acids content in lipid fractions, in vitro digestibility, reducing sugars and polyphenols contents. The highest crude and true protein contents were obtained in the thermal concentrate, but most carotenes and xanthophylls were coprecipitated during fractionation of the juice with Superfloc A-115 flocculant. Concentrates obtained from lucerne juice contained about twice as much unsaturated fatty acids than green fodder.
\end{abstract}

KEY WORDS: leaf protein concentrate, chemical composition, in vitro digestibility

\section{INTRODUCTION}

Protein concentrates obtained from green parts of cultivated plants constitute a non-conventional source of proteins used as an additive to non-ruminant animal feed. The use of chloroplastic fractions in human nutrition is limited by its negative sensory properties. These may be improved by extraction of pigments with organic solvents (Favati et al., 1988;, Hernández et al., 1988), or by 
exposition to the plasteine reaction (Savangikar and Joshi, 1979; Baraniak, 1982).

The cytoplasmic protein fraction is much more useful. Its chemical composition and functional properties determine its suitability for use as protein substitutes in the human diet. This fraction is obtained in the process of fractionating plant juices by various methods of protein coagulation. However, because of the low efficiency of cytoplasmic agents, this is not an industrial process. This created the need for research on improving existing solutions or finding new ones that would be more profitable. The method of protein coagulation from plant juices is, next to the species of the plant used, the main factor limiting the quality of the preparations obtained. In this paper, the changes in the properties of chloroplastic agents occurring under the influence of various factors used to coagulate the proteins were investigated.

\section{MATERIAL AND METHODS}

The material used was fresh lucerne var. Kleszczewska harvested in the pre-flowering phase. The juice was extracted by pressing the green fodder in an expeller. The green forage had previously been crushed in a screw press. The fibrous material was filtered off through a $0.15 \mathrm{~mm}=100$ mesh sieve.

Chloroplastic concentrates were condensed by: centrifugation $(3000 \mathrm{rpm})$, heat treatment $(328 \mathrm{~K})$, and by anionic flocculants, Superfloc A-115 and Magnafloc LT-26 (in the amounts of $300 \mathrm{mg} / \mathrm{dm}^{3}$ of juice previously alkalized to $\mathrm{pH} 7.5$ with $2 \mathrm{M} \mathrm{NaOH}$ ). The preparations obtained in this way were centrifuged, washed with distilled water twice, dried at in $323 \mathrm{~K}$ (in a vacuum drier), and after grinding, kept at a temperature of about $279 \mathrm{~K}$.

The crude protein content $(\mathrm{N} \times 6.25)$ was determined by the Kjeldahl method using an automatic Kiel-Foss apparatus; the true protein content was determined as the fraction that was insoluble in $10 \%$ trichloroacetic acid.

Protein fractionation was performed by shaking $(2 \times 2 h)$ with phosphorus buffer of $\mathrm{pH}=7.0$ (fraction I), and then with $0.1 \mathrm{M} \mathrm{NaOH}(2 \times 1 \mathrm{~h}$-fraction II).

Carotenes and xanthophyll contents were determined according Bubicz (1965). Chlorophylls were assayed spectrophotometrically after the extraction with acetone (Arnon, 1960).

Polyphenols were extracted with a mixture of methanol: water $(1: 1, \mathrm{pH}=4.0)$ and their total content was estimated using the Folin-Ciocalteau method (Swain and Hillis, 1959) with chlorogenic acid as the standard.

The level of water-soluble pigment was measured spectrophotometrically $\left(\mathrm{A}_{4300}\right)$, in a $0.5 \mathrm{ml}$ sample diluted with $9.5 \mathrm{ml}$ of Tris buffer $\mathrm{pH}=7.5$. 
The reducing sugars content in filtrates was determined using DNS (3,5-dinitrosalicyllic acid) (Miller, 1959). Concentrates were subjected to hydrolysis with $6 \mathrm{M} \mathrm{HCl}$, the filtrates were neutralized and the sugar content was estimated in the filtrate using the method described above.

Fats were extracted with hexane, and the level of individual fatty acids was determined by gas chromatography (Lima et al., 1965). Enzymatic hydrolysis was carried out with pepsin, trypsin, pancreatin and papain for 2,4 and $6 \mathrm{~h}$. The degree of digestion in vitro was determined by estimating the protein content (Lowry et al.,1951), using bovine serum albumin as the standard.

\section{RESULTS AND DISCUSSION}

The amount of crude protein ranged from 33 to $44 \%$ (Table 1). The highest levels of both the crude and the true protein were found in the preparation obtained in the process of thermal fractionation of the juice. The results for the preparations condensed using flocculants were somewhat lower than reported by Baraniak (1990) after fractionating the proteins of the Boja lucerne variety with flocculants produced by Magnafloc, as well as by Fiorentini and Galoppini (1980), using the polyelectrolyte Superfloc A-150 for precipitation of the chloroplastic fraction of this plant. The current research was done on the lucerne material gathered during the first spring swath. The protein content in such material is, therefore, lowest compared to later (autumn) cuttings. This lowers

TABLE 1

Protein content and yield of protein of concentrates obtained from lucerne juice by various methods

\begin{tabular}{lccccc}
\hline Concentrate & $\begin{array}{c}\text { Crude } \\
\text { protein }\end{array}$ & $\begin{array}{c}\text { True } \\
\text { protein }\end{array}$ & $\begin{array}{c}\text { True } \\
\text { protein } \\
\% \text { of } \\
\text { total }\end{array}$ & $\begin{array}{c}\text { Protein } \\
\mathrm{g} / \mathrm{dm}^{3} \\
\text { of } \\
\text { juice }\end{array}$ & $\begin{array}{c}\text { Protein } \\
\% \text { of } \\
\text { juice } \\
\text { protein }\end{array}$ \\
\hline Fresh lucernc & 19.7 & 16.0 & 81 & - & - \\
Thermal & 44.2 & 28.3 & 64 & 19.0 & 53 \\
Magnafloc LT-26 & 38.8 & 24.2 & 62 & 14.8 & 41 \\
Superfloc A-115 & 33.3 & 20.9 & 63 & 14.6 & 41 \\
Green juice & 37.6 & 18.9 & 50 & 35.8 & 100 \\
\hline
\end{tabular}

the level of proteins in pressed juice, as well as in the preparations obtained from that juice. The efficiency of the process (Table 1) is, therefore, also lower. The carotenoid level in the investigated concentrates (the highest amounts of these compounds are in the preparation flocculated with Superfloc, Table 2) was higher than that described by Baraniak (1990). It is interesting that high 
TABLE 2

The chemical composition of protein concentrates obtained from lucerne juice by various methods

\begin{tabular}{lccccc}
\hline Component & Fresh lucerne & Centrifugal & Thcrmal & $\begin{array}{c}\text { Magnafloc } \\
\text { LT-26 }\end{array}$ & $\begin{array}{c}\text { Supcrfloc } \\
\text { A-115 }\end{array}$ \\
\hline $\begin{array}{l}\text { Carotenes, mg/kg DM } \\
\text { Carotenes, \% of total }\end{array}$ & 48.62 & 320.55 & 272.46 & 283.15 & 411.37 \\
$\quad$ carotcnoids & 18 & 36 & 37 & 42 & 38 \\
Xanthophylls, \% DM & 223.7 & 567.0 & 459.4 & 384.5 & 662.5 \\
Chlorophyll & & & & & \\
$\quad$, mg/kg DM & 1.25 & 5.15 & 2.49 & 71 & 0.84 \\
,a" \% of total & 57 & 78 & 71 & 79 & 66 \\
„b" mg/kg DM & 1.02 & 1.43 & 1.01 & 0.45 & 0.43 \\
Reducing sugars, \% & - & 16.3 & 15.5 & 11.5 & 8.25 \\
Fat, \% & 2.3 & 11.1 & 8.0 & 9.0 & 6.3 \\
Polyphenols, \% & 1.41 & 3.42 & 3.44 & 1.89 & 2.30 \\
Spectrun, $\lambda$ max & & & & & \\
peak I & 215.0 & 255.5 & 269.5 & 262.5 & 264.5 \\
peak II & 290.5 & 328.0 & 350.0 & 338.0 & 342.0 \\
\hline
\end{tabular}

concentration of carotens, being direct precursors of vitamin A, was found, however it was lower than obtained by Ostrowski-Meissner et al., (19859) what could be probably attributed to different material and analytical procedure used.

For the past few years special attention has been paid to the possibilities of using legume preparations not only as source of additional protein in nutrition, but also because of their high level of carotenes and xanthophylls (several times higher that in green fodder) and chlorophylls as a natural colouring factor. Because of the presence of the $\beta$-ionon ring the carotenes have antioxidizing properties. The importance of vitamin A, which derives from carotenes, in fighting cancer is in the protection it provides from genotoxic cancerogens which, along with epigenetic cancerogenes, participate in the process of initiation - the first phase of cancers development.

Antioxdizing properties are also characteristic for phenolic compounds that are considered antinutrients. Their content in the obtained preparation depends on the method used for precipitation, the greatest amount was received in the preparation obtained by the thermal method, while the smallest amount, in the one flocculated with the polyelectrolyte, Magnafloc LT-26 (Table 2). The differences in protein levels and solubility (Table 3), and in the content of phenol compounds point to the variability of interactions between the juice compounds under the influence used in the preparation procedures. Formation of linkages between phenol compounds and quinones, the products of enzymatic oxidation of phenolic compounds with the $\varepsilon$-amine group of lysine, confirms the low hydrolytic susceptibility of the obtained preparations (Table 4). Papain and pepsin seemed to be most efficient when used in the concentrates obtained using 
TABLE 3

The composition of protein fraction of protein concentrates obtained from lucernc juice by various methods

\begin{tabular}{lcccccc}
\hline & \multicolumn{2}{c}{ Fraction 1 , soluble in buffer $\mathrm{pH}=7.0$} & \multicolumn{2}{c}{ Fraction I1, soluble in 0.1 M NaOH } \\
\hline & $\begin{array}{c}\text { Protein } \\
\%\end{array}$ & $\begin{array}{c}\text { Reducing } \\
\text { sugars }\end{array}$ & $\begin{array}{c}\text { Pigments } \\
\%\end{array}$ & $\begin{array}{c}\text { Protein } \\
\%\end{array}$ & $\begin{array}{c}\text { Reducing } \\
\text { sugars }\end{array}$ & $\begin{array}{c}\text { Pigments } \\
\%\end{array}$ \\
\hline Fresh lucerne & 59 & 2.3 & 1.30 & 15 & 0.1 & 0.32 \\
Thermal & 32 & 1.5 & 1.41 & 16 & 0.2 & 2.0 \\
Magnafloc LT-26 & 38 & 0.6 & 1.02 & 12 & 0.2 & 1.51 \\
Superfloc A-115 & 33 & 0.3 & 1.37 & 13 & 0.7 & 0.46 \\
\hline
\end{tabular}

TABLE 4 In vitro digestibillity (\%) of protein concentrates obtained from lucerne juice by various methods

\begin{tabular}{|c|c|c|c|c|c|c|}
\hline Components & Centrifugal & Thermal & $\begin{array}{c}\text { Magnafloc } \\
\text { LT-26 }\end{array}$ & $\begin{array}{c}\text { Superfloc } \\
\text { A-115 }\end{array}$ & Cascin & $\begin{array}{l}\text { Bovine } \\
\text { albumin }\end{array}$ \\
\hline \multicolumn{7}{|l|}{ Trypsin } \\
\hline $2 \mathrm{~h}$ & 5 & 20 & 5 & 30 & 50 & 60 \\
\hline $4 h$ & 10 & 40 & 15 & 40 & 60 & 85 \\
\hline $6 \mathrm{~h}$ & 15 & 60 & 25 & 50 & 85 & 100 \\
\hline \multicolumn{7}{|l|}{ Pepsin } \\
\hline $2 \mathrm{~h}$ & 5 & 5 & 10 & 35 & 60 & 45 \\
\hline $4 \mathrm{~h}$ & 20 & 20 & 50 & 50 & 80 & 70 \\
\hline $6 \mathrm{~h}$ & 35 & 35 & 70 & 65 & 80 & 70 \\
\hline \multicolumn{7}{|l|}{ Pancreatin } \\
\hline $2 \mathrm{~h}$ & 5 & 5 & 5 & 10 & 70 & 20 \\
\hline $4 \mathrm{~h}$ & 10 & 15 & 10 & 15 & 100 & 30 \\
\hline $6 \mathrm{~h}$ & 15 & 35 & 15 & 20 & 100 & 40 \\
\hline \multicolumn{7}{|l|}{ Papain } \\
\hline $2 \mathrm{~h}$ & 10 & 5 & 25 & 30 & 40 & 60 \\
\hline $4 \mathrm{~h}$ & 15 & 15 & 40 & 40 & 60 & 80 \\
\hline $6 \mathrm{~h}$ & 25 & 30 & 65 & 50 & 85 & 100 \\
\hline
\end{tabular}

flocculants, while trypsin was the most efficient for the concentrate precipitated thermally. The durability of linkages between chlorogenic acid and proteins is evidenced by the lack of a peak at $520 \mathrm{~nm}$ in the absorption spectrum of polyphenols extracted from the investigated concentrates (Table 2). The absorption maxima in the range of $250-270$ and $320-350 \mathrm{~nm}$, were the same as obtained by Hernández et al. (1991) and arc characteristic for flavones. The results of hydrolysis, carried out with individual enzymes, are lower than those obtained by two-step hydrolysis (Bagchdi, 1993; Proydak and Kireeva, 1993). Also, in vitro digestibility was much higher because the preparations were subjected to the influence of many enzymes of various activities. In this paper, the hydrolysis with single enzymes was used in order to show the variability of the 
TABLE 5

The fatty acids content $(\%)$ in lipid fraction of protein concentrates obtained from lucerne juice by various methods

\begin{tabular}{cccccc}
\hline Fatty acids & Fresh lucerne & Centrifugal & Thermal & Magnafloc LT-26 & Superfoc A-115 \\
\hline $14: 0$ & 3.21 & 3.38 & 1.93 & 2.59 & 2.07 \\
$16: 0$ & 41.87 & 29.73 & 33.04 & 40.35 & 33.97 \\
$16: 1$ & 0.00 & 1.24 & 1.61 & 3.02 & 2.29 \\
$18: 0$ & 8.68 & 3.36 & 4.58 & 5.47 & 5.28 \\
$18: 1$ & 6.60 & 2.70 & 3.27 & 2.92 & 3.59 \\
$18: 2$ & 15.85 & 21.00 & 21.56 & 19.41 & 16.66 \\
$18: 3$ & 2.08 & 38.56 & 33.25 & 26.24 & 30.43 \\
$18: 4$ & 0.00 & 0.00 & 0.00 & 0.00 & 5.72 \\
$20: 0$ & 21.70 & 0.00 & 0.74 & 0.00 & 0.00 \\
\hline
\end{tabular}

features of isolated preparations depending on the precipitation method used. During coagulation of proteins from the juice, sugars also form complexes with glycolipids from photosynthesizing membranes, i.e. the main fats occurring in chloroplastic concentrates. Contact of solvent with fat molecules is only possible after disrupting the complexes formed and the solvents used must have the ability to create hydrogen bonds with sugars.

The differences in the amount of extracted fat (with the same solvent in the same conditions) and in the amount of sugars shown in this paper (Table 2), allow us to assume that the formed complexes are the most durable when using the flocculant Superfloc A-115 for condensed of the preparations, and the weakest when separating the chloroplast fractions by centrifuging.

The level of unsaturated fatty acids in the lipid fraction of the concentrates seems to be of particular interest. It was almost twice as high as in the initial green fodder (Table 5). Polyen acids are a source of essential unsaturated fatty acids (or nonsaturated fatty acids, NSF $A$ ), which are a necessary nutritional component of food. Therefore, it is important not to eliminate components rich in unsaturated fatty acids from human and animal diets. Using protein concentrates in nutrition allows supplying NSFA along with a greeat deal of proteins and carotenoids - precursors of vitamin A.

\section{CONCLUSIONS}

Chloroplastic concentrates obtained as the result of fractionating of lucerne juice constitute good source of unsaturated fatty acids, carotenes and xanthophylls. However, their in vitro digestibility was low in comparison to casein and bovine albumin. The digestion of protein by proteolytic enzymes depended on the kind of enzymes and methods used in preparing the concentrates. 


\section{REFERENCES}

Arnon M.J., 1960. Chemistry and Biochemistry of Plant Pigments. T.W. Goodwin (Editor). London, Academic Press

Bagchdi D.K., 1993. Studies on the utilisation of by-product leaves for leaf protein production. In: H.T. Ostrowski-Meissner (Edior). Procecdings of the $4^{\text {th }}$ International Conference on Leaf Protein Research, AFIC Publications, Sydney, pp. 51-56

Baraniak B., 1990. The effect of flocculant applied in the process of fractionating alfalfa juice on the chemical composition of the obtained protein concentrates. Anim. Feed Sci. Technol. 31, 305-311

Baraniak B., 1992. The obtaining of plastein by enzymatic hydrolysis of chloroplastic concentrate from lucerne juice (in Polish ). Przem. spoż . 46 (2), 52-53

Bubicz M., 1965. Occurence of carotenoids in fruits of the genus Berberis. Bull. Acad. Pol. Sci., Ser. Sci. Biol. 13, 251-255

Favati F., Fiorentini R., Galoppini G., 1988. Pigment cxtraction from alfalfa protein concentrates. Acta alim. 17, 239-244

Fiorentini R., Galoppini C., 1980. Produzione di concentrati proteici fogliari a destinazione umana. 1. Aspetti tecnologici. Agric. Ital. 19, 11-15

Hcrnández A., González G., Martínez C., 1988. Solvent extraction of alfalfa chloroplastic curds. J. Sci. Food Agric. 43, 67-73

Hernández T., Hernández A., Martínez C., 1991. Polyphenols in alfalfa leaf concentrates. J. Agric. Food Chem. 39, 1120-1122

Lima I.H., Richardson T., Stahmann M. A., 1965. Fatty acids in some leaf protcin concentrates. J. Agic. Food Chem. 13, 143-145

Lowry O., Rosebriught N. , Farr $\Lambda$., Randall R. J., 1951. Protcin measurement with Folin-phenol reagent. J. Biol. Chem. 193, 265-268

Miller G.E., 1959. Use of DNS a reagent for determination of reducing sugars. Anal. Chem. 31 , 26-428

Ostrowski-Meissner H.T., Jeffrey H.T., Wright S.W., Suarna C., 1989. Fxtrability and profiles of pigments in concentrated leaf extracts from lucerne grown under three climatic conditions in Australia. Ital. J. Food Sci., Proceedings of 3rd International Conference on Lcaf Protcin Research, pp. 158-160

Proydak N.I., Kireeva Y., 1993. Hydromechanic process for production of chloroplastic and cytoplasmic protein fractions from green alfalfa juice. In: H.T. Ostrowski-Meissner (Editor). Proceedings of the 4th Intcrnational Conference on Leaf Protein Research, $\Lambda F I C$ P'ublications, Sydney, pp. 115-120

Savangikar V.A., Joshi R.N., 1979. Modification of leaf protein concentrate by the use plastein reaction. J. Sci. Food Agric. 30, 899-905

Swain T., Hillis W.E., 1959. The phenolic constituents of Prunus domestica I. J. Sci. Food Agric. 10, 63-67 


\section{STRESZCZENIE}

Sklad chemiczny i strawność in vitro bialka koncentratów chloroplastycznych koagulowanych róźnymi metodami $z$ soku lucerny

Porównano skład chemiczny koncentratów białkowych z lucerny otrzymanych różnymi metodami. Koncentraty chloroplastyczne z soku lucerny (odm. Kleszczewka) wytrącano poprzez wirowanie (3000 obr./min), termicznie (328 K) lub flokulantami Magnafloc LT-26 i Superfloc A-115. W koncentratach oznaczono zawartość białka ogólnego i właściwego, poziom karotenoidów i chlorofili, ilość poszczególnych kwasów thuszczowych we frakcji thuszczu, strawność in vitro oraz zawartość cukrów redukujących i polifenoli.

Najwięcej białka właściwego i ogólnego zawierał koncentrat wytrącony termicznie $(28,3$ i $44,2 \%$ s.m., odpowiednio), natomiast najwięcej karotenów (411,4 mg/kg s.m.) i ksantofili (662,5\% s.m.) ulegało współstrąceniu z białkami soku frakcjonowanego flokulantem Superfloc A-115. Koncentraty otrzymanc $\mathrm{z}$ soku lucerny zawierały okolo dwukrotnie więcej nienasyconych kwasów thuszczowych niż zielonka. 